\title{
Copyright Legal Protection of Writing Work on the Site of omgjakarta.com: Law Number 28 of 2014
}

\author{
Emia Alemina $^{1 *}$, Budi Santoso ${ }^{2}$, Sukirno $^{3}$ \\ \{emiaalemina17@gmail.com ${ }^{*}$, budisusantomg@lecturer.undip.ac.id ${ }^{2}$, sukirno.fh@live.undip.ac.id ${ }^{3}$ \} \\ Fakultas Hukum, Universitas Diponegoro, Jl. Prof. H. Soedarto, S.H., Semarang, Indonesia 50275 1,2,3
}

\begin{abstract}
Copyright is a term that describes a right granted to the creator for their creation. Writing Paper is one of the copyrighted works protected by Law Number 28 of 2014 concerning Copyright. However, in practice, there are still copyright infringement of papers as in the case on the site Omgjakarta.com which announces the writing of the Do and Don't Culture Shock, Getting Around, Eat like A Local and City Escapes which is done without permission on the Author. The aim of this research is firstly, to find out the legal protection of copyrighted works used commercially without the permission of the copyright holders of written works, secondly, to find out the implementation of Law Number 28 of 2014 concerning Copyright in the case of the Supreme Court's Decision Number 918 K/Pdt.Sus-HKI/2018. The results showed that within the Supreme Court Decree No. 918K/Pdt.Sus-HKI/2018, users of copyrighted works that are used commercially for personal gain must obtain permission from the copyright holder of the written work. The Copyright Act provides copyright protection to Copyright Holders The Written Paper. This is done to protect the rights held by the Written Copyright holders. Violation of copyrighted works is expressly regulated in Article 9 of Law Number 28 Of 2014 concerning Copyrights in order to protect the rights held by holders of Copyrighted Papers.
\end{abstract}

Keywords: Copyright, Writing, Omgjakarta.com

\section{Introduction}

As happened in the case of copyright infringement on papers that were announced without permission to the copyright holders, namely Aju Trisna, Vio Kusuma Putra Jowono, Darrel Arowiguna Jowono, Haryanto Chang, James Weston as the Defendant used the Paper from James Adrian Laime as the Plaintiff to the interests of the omgjakarta.com site. Papers on the site omgjakarta.com namely Do and Don't Culture Shock, Getting Around, Eat Like A Local and City Escapes have the same content, either in whole or in part with a Cita Karya with Registration Number 02773, 02768, 02766, 0276, 02769 the Plaintiff's. The act carried out by the Defendant is an act that enriches oneself or is selfish. So that James Adrian Laime as the Plaintiff knows and is aware of the existence of economic rights in the Paper used for the site of the Omgjakarta.com by the Defendant, as the party that has used the Plaintiff's written works only for the Defendant's interests and profits. In accordance with Law Number 28 Of 2014 concerning Copyright,[1] especially in paragraph 1 concerning Economic Rights of the Author or Copyright holder Article 9 paragraph (3) states, "Anyone without the author's permission or Copyright Holder is prohibited from making a Duplication and/or Use Commercially Creation." 
Copyright is one of the rights owned by someone who is, hereinafter referred to as the creator which includes art, culture, literature and science as mentioned in Article 1 of Law No.28 of 2014. This starts from the emergence of Law Number 6 of 1982 concerning Copyrights but in its progress the implementation of national development has increased, especially in the fields of arts and literature as well as to amend Law Number 6 of 1982, Law No. 7 of 1987 was issued which was then amended by giving birth to an Act Law Number 12 of 1997 due to Indonesia's participation in the agreement on Trade Aspects of Intellectual Property Rights (Agreement on Trade Related Aspects of Intellectual Property Right, Including Trade in Counterfeit Goods) which is part of the Agreement on the Establishment of the World Trade Organization Trade Organization) passed by law. Changes still occur with the issuance of Law Number 19 of 2002 because it is considered that there is still a need for renewal and the latest renewal is Law Number 28 of 2014 concerning Copyright which is in force today.

Copyright exclusive rights owned by the creator of the work of his creation which then to be published on the mass media with the aim to protect the work both morally and economically. It is aid that exclusive rights have 2 concepts, namely economic rights and moral rights which is very important for copyright. Said to be important because with these two concepts copyright can be valued more in existence.

In Indonesia, Copyright is regulated in Law Number 28 of 2014 which regulates every work of a person, hereinafter referred to as a protected creator, without reducing restrictions in accordance with statutory regulations. In article 40 of Law Number 28 of 2014 concerning Copyrights contains types of protected works.

Besides protected works, there are also unprotected works contained in Article 41 of Law Number 28 of 2014. Unprotected works include:

a) A work that has not been realized in tangible form;

b) Every idea, procedure, system, method, concept, principle, finding or data even though it has been disclosed, is stated. Described, explained, or combined in a work; and

c) Tools, objects, or products created only to solve technical problems or whose form is intended only for functional needs.

The existence of rules regarding protected and unprotected works will minimize misunderstandings and know which works can be protected and not protected. As regulated in Article 58 paragraph (1) of Law Number 28 of 2014 relating to the period of validity of economic rights over a work, i.e. protection of copyright which includes a work in the form of:

1) Books, pamphlets, and all other written works;

2) Lectures, lectures, speeches and other similar creations;

3) Props are made for the benefit of education and science;

4) Songs or music with or without text;

5) Drama, musical drama, dance, choreography, puppetry, and pantomime;

6) Art works in all forms such as paintings, drawings, calligraphy, sculpture, sculpture, or collage;

7) Architectural works;

8) Map; and

9) Batik art or other motifs.

In the article explained that the legal protection of the work is valid for the life of the creator and continues for 70 years after the creator died from January 1 the following year. 
Melisa Pawloski stated the idea that authors and artists have moral rights in their creations, also called moral droit originating from France during the French revolutionary period. True morality has been described as "a collection of prerogative rights, all of which begin with the need to preserve the integrity of the intellectual work and personality of the writer. The moral rights doctrine seeks to secure the intimate ties that exist between literary or artistic works and the personality of the author.In France, the main justification for moral rights is the idea that the work or art is an extension of the artist's personality and expression of his innermost being.The importance of moral rights is to prevent attacks on the person to a greater extent than for To prevent attacks on work.[2] Categorically, the creations include works of science, works of art and literary works. The works of science itself include books, published works and other written works. This form of protection will become evident if it violates both the essence of moral rights, namely the right of paternity or right of integrity, when the violation occurs the creator can determine the violator to restore rights and interests.

In this growing age with so sophisticated technology, many people are also developing from all sides. Technology that is already sophisticated and easy to access is also used to post the work they have created. The work of creation is not only photos, videos or songs but also works in the form of writing which is often uploaded on a website. Back then, people saw writing only through books and forms or in bookstores, libraries, newspapers, magazines but with the internet technology that can quickly access something that is wanted to be uploaded then people prefer to announce their writing through a website. Precisely, with the existing development, this thing is misused by some audiences for its own interests. Where what often happens in this paper is the act of plagiarism. Where this act of plagiarism means the duplication in the writings of others, the true copying of the works must be done with permission from the creator or copyright holder as stated in Article 9 with Law Number 28 of 2014. In practice, it is even on the contrary, it is rare for anyone to do prior permission to the creator or copyright holder and this is what causes the dispute to occur in court. The criminal provisions governing the duplication of copyrighted works without permission, namely in Article 113 of Law Number 28 Of 2014 concerning copyrights which read: Anyone who without the rights and/or without permission of the Author or the Copyright holder commits a violation of the Creator's economic rights as referred to in Article 9 paragraph (1) letter a, letter $b$, letter $e$, and/or letter $g$ for Commercial Use shall be punished with a maximum imprisonment of 4 (four) years and/or a maximum fine of IDR 1,000,000,000, 00 (one billion rupiah).

Even though there is a copyright law, there are still problems in copying the paper, as the case described above is also influenced by the public's knowledge that is still unfamiliar with existing regulations. Based on the description above, it is interesting to study further in the form of a thesis with the title "Copyright Legal Protection of Writing Work on the Site of omgjakarta.com According to Law Number 28 of 2014 (Case Study of the Decision of the Supreme Court Number 918K/ Pdt.Sus-HKI/2018)."

Based on the background of the research described above, and in order not to deviate from the subject matter to be discussed, the problem is formulated as follows:

a. How is the legal protection for copyright holders of written works based on Law No. 28 of 2014 on the Decision of the Supreme Court Number 918K/Pdt.Sus-HKI/2018?

b. How is the implementation of Law No. 28 of 2014 in the case of Decision Number 918 K/Pdt.Sus-HKI/2018?

The objectives of this study are: 
a. To find out the legal protection of copyright holders of written works based on Law No.28 of 2014 in the Decision of the Supreme Court Number 918K/Pdt.Sus$\mathrm{HKI} / 2018$

b. To find out the implementation of Law Number 28 Of 2018 on the Decision of the Supreme Court Number 918 K/Pdt.Sus-HKI/2018

\section{Method}

\subsection{Approach Method}

The approach method used in this research is a normative juridical approach with descriptive analytical research specifications. The data used is secondary data. Secondary data is data obtained by a researcher indirectly from the source (research object), but through other sources.[2] Secondary data is data obtained from library materials, the method used in analyzing and processing the collected data is qualitative analysis.

\section{Research Results and Discussion}

\subsection{Legal Protection of Copyright Holders of Written Paper Based on Law Number 28 of 2014 in the Supreme Court Decree Number 918K/Pdt.Sus-HKI/2018}

\subsubsection{Arrangement of protection of economic rights over written works according to Law Number 28 of 2014 concerning Copyright}

According to Setiono, legal protection is an action or method taken to protect the community from arbitrary actions taken by the authorities that are not in accordance with existing regulations, so that the community continues to feel safe and secure and can enjoy its dignity as a human being.[3]

Violations that occur in the case of copyright can be classified as violations of economic rights or moral rights. We can see in Article 4 of Law Number 28 of 2014 concerning copyright that reads:

Copyright as referred to in Article 3 letter a is an exclusive right consisting of moral rights and economic rights.

So, from that article it can be seen that copyright consists of economic rights and moral rights. However, it does not rule out the possibility of copyright infringement that violates economic rights and moral rights. In article 5 of Law Number 28 of 2014 concerning Copyright, it states that the protection of the creator's moral rights to:

a) keep the name or not the name on the copy in connection with the use of his work for the public

b) Use his alias or pseudonym

c) Change the Creation according to propriety in society

d) Change the title and subtitle of the Work

e) Retain his rights in the event of Distortion of the Work, mutilation of the Work, modification of the Work, or matters which are detrimental to his honor or reputation. 
The period of protection is granted indefinitely in accordance with Article 57 paragraph (1) of Law Number 28 of 2014 concerning Copyright. In addition, Article 8 of Law Number 28 of 2014 concerning Copyrights stipulates that the protection of the economic right to:

a) Issuance of Work;

b) Duplication of a Work in all its forms;

c) Translation of Creation;

d) Adaptation, arrangement, or transformation of the Work;

e) Distribution of Works or copies thereof;

f) Performing Works;

g) Announcement of the Work;

h) Communication of Creation; and

i) Tenants of the Work.

Protection of economic rights is given for the life of the creator and continues for the life of the creator and continues for 70 years after the Creator dies, starting from January 1 of the following year as regulated in Article 58 paragraph (1) of Law No. 28 of 2014 concerning Copyright. If the copyright is owned by a legal entity, the protection period is 50 years from the time the announcement was made. The type of work whose protection is given during the life of the creator plus 70 years after the author dies as stipulated in Article 58 of Law No. 28 of 2014 concerning Copyright.

\subsubsection{Forms of Protection for copyright holders according to Law Number 28 of 2014}

A contract is a legal act based on an agreement to cause a legal effect. Under Article 1338 of the Civil Code (KUH Perdata) known as the Pacta Sunt Servanda, namely "all treaties made legally apply as a law for those who make them. In making agreements, it can be recognized the principle of freedom of contract which is regulated in Article 1320 of the Civil Code (Civil Code), namely through:

1) Agreement from those who bind themselves;

2) The ability to make one engagement;

3) A certain thing;

4) A lawful cause

An agreement is said to be valid if both parties who entered into the agreement have an agreement to do the agreement then both parties are competent in making an agreement which means meeting the competent requirements of a person making an agreement that is an adult (21 years old) or a person married and not in forgiveness. The agreed agreement has something to be achieved in this case is the copyright holder as the object of the agreement and the original owner of the written work. Furthermore, a hala cause does not mean that it is contrary to applicable law.

So with this principle, if you want to make an announcement/copy the copyright holder, you can ask for your rights. Especially the royalty rights if the writing is uploaded on a site for commercial purposes. Which is an effort to protect the good name of the copyright holder and also protect the interests of the copyright holder.

In contrast to this case, where the Defendants did is make an announcement/copying on an Internet site with the domain name www.omgjakarat.com without first entering into an agreement with the Plaintiff. This proves that in this case there was no clear agreement between the parties involved. Whereas in Law Number 28 of 2014 concerning Copyright 
clearly regulates the limitations on a person's creation contained in article 9 paragraph (3) which reads:

Article 9

Any person without the author's permission or copyright holder is prohibited from making duplication and/or commercial use of the work.

In Article 9 above it is clear that anyone who wishes to copy and/or use must first obtain permission from the creator or copyright holder, but we can see in the case that there was no permission or agreement to copy the works. When there is no agreement between the user of the copyright of the written work and the copyright holder of the written work, the copyright holder can protect his rights.

\subsubsection{Criminal sanctions}

Based on Article 9 paragraph (3) of Law Number 28 of 2014, the above case meets the elements contained in Article 9 paragraph (3) of Law Number 28 of 2014. Then, for those contained in this Article to be carried out by the User right copyrighted papers (Defendants) and Copyrighted copyright holders (Plaintiffs). Sanctions supporting what is contained in Article 9 paragraph (3) of Law Number 28 Of 2014 concerning Copyright contained in the following articles include:

Article 96

- Creators, holders of copyrights and/or holders of related rights or their heirs who suffer loss of economic rights are entitled to receive compensation.

- Compensation as referred to in paragraph (1) shall be provided and included at the same time in the court ruling on criminal cases of Copyright and/or Related Rights.

- Compensation Payment to the Author, Rightsholder

Copyrights and/or owners of the Related Rights shall be paid no later than 6 (six) months after the court decision has permanent legal force.

Article 99

(1) The creator, copyright holder, or owner of related rights has the right to submit compensation claim to the Commercial Court for violation of copyright or related rights product.

(2) The claim for compensation as referred to in paragraph (1) may be in the form of a request to surrender all or part of the income derived from the holding of lectures, scientific meetings, performances or exhibitions of works which are the result of infringement of Copyright or Related Right products.

(3) In addition to the lawsuit as referred to in paragraph (1), the Creator, the Copyright Holder, or the holder of the Right to Link can request a decision on the provision or interlocutory decision from the Commercial Court to:

requesting the confiscation of a Work by Announcement or Duplication, and/or the Duplication tool used to produce a Work resulting from infringement of Copyright and Related Right Products; and/or stop the activities of Announcement, 
Distribution, Communication and/or Duplication of a Work which is the result of a violation of Copyright and Related Rights products.

Article 113

(2) Every person who fulfills the elements referred to in paragraph (3) committed in the form of piracy, shall be sentenced to a maximum imprisonment of 10 (ten) years and/or a maximum fine of IDR 4,000,000,000.00 (four billion rupiah).

If specified as contained in Article 115 listed above, there are elements as follows:

1) Subjective elements:

a) Error: fulfills the element of piracy

2) Objective elements:

a) The author: everyone who has the right to a work in the form of writing.

b) Against the law: using the copyright of written works without the consent of the copyright holder of the written work or his heirs

c) The act: commercial use, duplication, announcement, distribution, or communication on the Internet site with the domain name www.omgjakarta.com

d) Object: creation in the form of writing

\subsection{Implementation of Law No. 28 of 2014 in the case of Decision Number 918 K/Pdt.Sus-HKI/2018}

To determine whether a work is included in the scope of protected work as stipulated in the 2002 UUHC, is an answer which is not too easy to give. This is because each country regulates the types of protected works in addition to having to be based on conformity with applicable international provisions (the Bern Convention) also given the freedom to determine certain other works to be protected, Article 12 of the UUHC in addition to regulating the protection of books, programs computers, pamphlets, and appearance (published) written works, also provides protection for all other written works. According to this provision, it can be said that only written works in the fields of art, literature and science will obtain legal protection. However, in other countries written works in the form of business letters or work orders, for example, are also classified as protected works.[3]

Even though it is protected by law, it does not anticipate copyright infringement. The Copyright Law has been amended 4 times and is in effect up to now, namely Law Number 28 of 2014. To overcome violations that occur between the user of the copyright of the written work and the copyright holder of the written work as the implementation of Law Number 28 of 2014 concerning Copyright, which explains that the Copyright Holder has moral rights and economic rights.

Regarding the dispute of copyright infringement that occurred in the Supreme Court Decree No. 918K/Pdt.Sus-HKI/2018 that occurred between the user of copyrighted works (Defendants) and the copyright holders of written works (Plaintiffs). The multiplication of written works by the Defendants is the reason for the occurrence of copyright infringement on this paper. The Defendant did not realize that there was protection for the copyright holders of written works if they did not first obtain permission in the form of an agreement. 
If there is a copyright violation then the settlement of the dispute is required. Civil dispute that occurs in each copyright violation, attempted settlement of dispute, arbitration or court. Law Number 28 of 2014 concerning Copyright places the settlement of civil trumpets that can be resolved quickly, cheaply and at a low cost in accordance with the principles of justice adopted by the Indonesian civil justice system. This Law places alternative dispute settlement in the first order, followed by settlement through arbitration placed second and court placed third. The civil court authorized in this case is the Commercial Court. Other courts besides the Commercial court are not authorized to handle the settlement of the Copyright Sangketa.[3]

In resolving the case, it was decided at the first level by the Jakarta Commercial Court No.12 K/Pdt.Sus-HKI/2017/PN.Niaga.Jkt.Pst., Juncto No. 56/Pdt.Sus.Hak Cipta/2017/PN.Niaga.Jkt.Pst. which does not satisfy the litigants. With regard to the Decision of the Commercial Court pronounced in a hearing open to the public, an appeal can only be filed. An appeal shall be submitted no later than 14 (fourteen) days from the date the Commercial Court Decision is made in an open hearing or notified to the Parties. [3] Decision at the cassation level by the Supreme Court with a decision No.12 K/Pdt.SusHKI/2017/PN.Niaga.Jkt.Pst., Juncto No. 56/Pdt.Sus.Hak Cipta/2017/PN.Niaga.Jkt.Pst. with the verdict the Panel of Judges sentenced the Defendant to pay material damages in the amount of IDR 2,788,000,000.00 (two billion seven hundred eighty eight million rupiahs) and immaterial losses in the amount of IDR 2,000,000,000.00 (two billion rupiah). And punish the Defendants for paying forced money (dwangsom) for late payment of compensation amounting to IDR 50,000,000 (fifty million) per day.

It is revealed that the development of the age will also affect the surrounding environment which will be a challenge for the future. Like what someone used to if they want to see other people's work, they have to go to bookstores, libraries, and so on. But if we look at it now with technology that is so sophisticated, everything we want to do can be processed quickly.

The drastic change of communication actors from using paper to using electronics has changed the existing legal system. The pattern of information retrieval through electronic nature called cyberspace (cyberspaces) has become a new trend in social life. Therefore, in the future Indonesia, as revealed by the Indonesian Electro Communication and Information Society (MEKII), needs to have:[3]

a) An internet watchdog and cyberlaw to regulate some important things in internet usage.

b) The supervisory body will be tasked with preparing legal infrastructure related to Indonesian internet crime.

c) A clearer reinterpretation of the Criminal Code.

d) Government protection for privacy through cyberlaw.

e) Expansion of the meaning of the Civil Code, the Copyright Act and the Trademark Rights Act in relation to this.

f) Legal use of online contracts, privacy, e-commerce, electronic payments, homepage maker responsibilities, e-mail and chat.

\section{Conclusion}

Based on the research results that have been described, the conclusions can be drawn as follows: 
1. Legal protection of copyright has been regulated in Law Number 28 of 2014. Legal protection of copyright is classified into two namely economic rights and moral rights in which the protection of economic rights can be seen in Article 8 of Law Number 28 of 2014 while the protection of moral rights can be seen in Article 5 of Law Number 28 of 2014. However, in the development of increasingly sophisticated technology, it makes the copyright user forget what is the legal protection of copyright, as happened on the site omgjakarta.com which makes an announcement without prior permission from the author of the written work, contained in Article 9 paragraph (3) of Law Number 28 Of 2014.

2. Implementation of Law Number 28 Of 2014 in the Decision of the Supreme Court Number $918 K /$ Pdt.Sus-HKI/2018 can be said to have not been carried out optimally by the parties involved, the copyright user is still not aware of the rights owned by the creator as evidenced by making an announcement without permission of the copyright holder of the paper. It can be said that the implementation of Article 9 paragraph (3) of Law Number 28 Of 2014 concerning Copyrights has not been fully fulfilled.

\section{References}

[1] Law Number 28 of 2014 concerning Copyright. .

[2] H. Soelistyo, Hak Cipta tanpa hak moral. Jakarta: Rajawali Pers, 2011.

[3] Setiono, "Rule of Law," Universitas Sebelas Maret, 2004. 